Proceedings of the 2018 International Scientific Conference 'Economic Sciences for Agribusiness and Rural Economy' No 1, Warsaw, 7-8 June 2018, pp. 21-27

\title{
HORIZONTAL INTEGRATION PROCESSES IN THE LIGHT OF THE PARADIGM OF INDUSTRIAL AND SUSTAINABLE DEVELOPMENT OF AGRICULTURE - CASE STUDY OF FRUIT AND VEGETABLE PRODUCERS
}

\author{
Anna Matuszczak, PhD¹, Associate Professor; Maryla Bieniek-Majka, PhD² \\ ${ }^{1}$ Faculty of Economics, Poznan University of Economics and Business \\ ${ }^{2}$ Institute of Economics, Kujawy and Pomorze University in Bydgoszcz
}

\begin{abstract}
The aim of this article was to initiate a discussion on the possibility of implementing the paradigm of sustainable agriculture by integrated fruit and vegetable producers. On the basis of the literature review the concept of industrial and sustainable agriculture and the dual model combining the advantages of both ideas were presented. Research has shown that institutional solutions have inspired horticulturists to join producer groups/ /organisations, resulting in an increase in the number of products offered on the domestic and international market. The strength of the correlation analysed between the number of producer groups/organisations and the selected characteristics of the fruit and vegetable market showed that integrated producers have a greater impact on the vegetable market than fruit. This impact had the properties of industrial agriculture. The structure of Polish groups/organisations in terms of their number allows us to suppose that, as small, often family businesses, they have premises to implement the paradigm of sustainable agriculture using the dual model. However, such an idea requires further long-term institutional support.
\end{abstract}

Keywords: industrial agriculture, sustainable agriculture, fruit and vegetable producer groups and organisations

JEL codes: Q01, Q13, F36

\section{INTRODUCTION}

Agriculture in Poland is at the stage of industrialisation, while the concept of sustainable development is of particular importance for the development of rural areas. However, the possibility of its implementation depends on the level of socio-economic development of a given country. The current level of this rural development in Poland means that the idea of sustainable development cannot be effectively implemented, as it may lead to a decrease in the welfare of society (Matysiak and Struś, 2015). On the other hand, there are strong legislative barriers and social contraindications for the continuation of land consolidation

${ }^{1}$ Corresponding author: al. Niepodległości 10,61-875 Poznań, Poland, anna.matuszczak@ue.poznan.pl, +48 618543017

${ }^{2}$ Corresponding author: Toruńska 55-57, 85-023 Bydgoszcz, Poland, m.bieniek-majka@kpsw.edu.pl, +48 663003403 
processes. It can therefore be concluded that the idea of integrating producers can provide a solution to the problem of the choice between industrial policy and sustainable development in agriculture.

\section{THEORETICAL BACKGROUND}

The agricultural issue is treated differently in underdeveloped countries, where the most acute problem is the insufficient growth of food production in relation to the demand at the existential minimum level, and differently in developed countries, where there is a significant disparity in the income of the agricultural population in relation to non-agricultural activities, a lower rate of return on capital employed and lower labour productivity of those employed in agriculture (Czyżewski and Guth, 2016). Developing countries, which also include Poland, solve agrarian issues using the model of industrial agriculture. It allows for an increase in agricultural production, which in turn allows the demand for food to be met. The undisputed successes in terms of increased production, efficiency and productivity made a positive impression. Such agriculture with a high level of concentration and specialisation, a large scale of production and high outlays of industrial resources is considered modern (Zegar, 2010).

From such a model of agrarian economy as industrial agriculture the idea of integration of agricultural producers is derived, as a kind of 'counterbalance' to the developing monopolies on the side of agriculture environment. Since the concentration processes in the sectors serving the agricultural sector are becoming stronger year by year, in the situation of a fragmented agrarian structure, the market position of the farmer is worsening. There is a kind of asymmetry of concentration which affects them to the disadvantage of others. According to Czyżewski and Guth, the power of farmers may be strengthened by producer groups and organisations. Unfortunately, the strength of these groups is too weak to defend the interests of farmers in real terms and to balance their position in the food production chain (Czyżewski and Guth, 2016).

However, it can be noted that after Poland's accession to the EU, the average size of agricultural holdings increased. As the area of land increases, the benefits of specialisation increase. The relation between the size of agricultural holdings and economic effects is explained by the farmers' determination to increase the scale of production (Smędzik-Ambroży, 2015). These factors contribute to a rapid increase in productivity and a question arises as to how to reconcile the need to increase agricultural production in order to meet the world's food challenges with care for the environment (Sobczyński, 2015). The model of industrial agriculture dominating in developed countries is based on microeconomic rationality and not on social rationality. The nature of the market mechanism requires the implementation of an industrial model in agriculture, however, attention is drawn to the need for alternative models. The model of sustainable agriculture is increasingly indicated, which requires the involvement of an institutional factor - state interventionism (Zegar, 2010).

In a globalised world, the potential for interventionism is diminishing and the market is moving towards microeconomic efficiency without solving either food or income problems. The evolution of CAP instruments is the strongest manifestation of the transition from the paradigm of industrial agriculture to its sustainability (Czyżewski and Guth, 2016). Although the level of support received by agriculture has been steadily decreasing in recent years, it is still high. On the one hand, the evolution of CAP instruments is a sign of a shift from the paradigm of industrial agriculture to its sustainability, and on the other hand, its universal nature is not conducive to achieving the objective of sustainable development of the agricultural sector (Smędzik-Ambroży, 2015).

The concept of sustainable development is derived from the concept of eco-development, which was created as a response of the international environment to global natural problems arising at the turn of the $70 \mathrm{~s}$ and $80 \mathrm{~s}$ of the 20 th century, when industrialised agriculture gradually violated its former harmony with the natural environment (Czyżewski and Smędzik-Ambroży, 2013). According to the new paradigm of the agrarian economy, the discrepancy between the micro and macro criteria is underlined by the contradiction between market and social competitiveness (Czyżewski and Czyżewski, 2015). 
The paradigm of sustainable agriculture as part of the new agricultural economy integrates social and environmental economic objectives, taking into account not only maximising the economic surplus for the needs of agricultural holdings. Attention is also paid to balancing the role of agriculture as a generator of food products benefiting from technological and biological progress, while at the same time reducing environmental pressures and increasing food quality and safety. Agriculture should be developed, but in a sustainable way. Industrial agriculture guarantees a growing supply of food, cheaper but with decreasing marginal usability due to highly intensive production methods, genetic modifications and a degraded environment. Sustainable agriculture is less efficient, relatively more expensive, but it guarantees the preservation of natural well-being (Czyżewski, 2007). Therefore, the industrial development path of agriculture was defined by Czyżewski and Guth as a 'quantity paradigm', and the model of sustainable agriculture as a 'quality paradigm' (Czyżewski and Guth, 2016). The two concepts are combined in a dual model. It combines the concepts of industrial agriculture, which strongly emphasizes the increase of work efficiency and the intensity of management of production resources, as well as socially sustainable agriculture taking into account environmental or health requirements (Henisz-Matuszczak, 2007).

\section{MATERIALS AND METHODS}

The aim of this study was to assess whether the integrated Polish horticulturists meet the requirements of the sustainable agriculture paradigm. Therefore, on the basis of a review of the literature and data from the Central Statistical Office, Ministry of Agriculture and Rural Development and the Agency for Restructuring and Modernization of Agriculture, changes in the fruit and vegetable market, the process of integration of fruit and vegetable producers in the long-term (12-year) period, were analysed. By means of correlation and dynamics analysis, the characteristics of the fruit and vegetable market were presented, which are shown in graphical and tabular form.

\section{RESULTS AND DISCUSSION}

In order to ensure sustainable development, attention should be paid to the need for alternation in the options exercised. The pendulum 'principle' allows for inhibiting or dynamising stimulators of economic development (Czyżewski, 2007). It is not easy, however, as the effects of institutional hysteresis connected with the liquidation of the centrally managed economy system are mentality issues hindering integration processes (Czyżewski, 2007). According to Grzelak, farmers in Poland appreciate the lower institutionalisation of their activities, understood as independence in terms of the possibility of choosing the channels for marketing their products, higher than the possible benefits resulting from membership in a production group (Grzelak, 2007). This thesis can be confirmed by the fact that the instruments of the support programme for newly established fruit and vegetable producer groups introduced in 2007 encouraged horticulturists to integrate, while radically changed in 2012 slowed down this process (Fig. 1). Polish gardeners were granted the amount of PLN 7.875 billion under this measure during considered period (including PLN 7.515 billion to cover part of eligible investment costs included in the approved recognition plan) $)^{3}$. According to many researchers (Krzyżanowska, 2011; Sobczak, Jabłońska and Olewnicki, 2013; Kopiński and Czernyszewicz, 2014), the period after Poland's accession to the European Union was a time of prosperity for Polish integrated producers of fruit and vegetables. Machine and technology parks have been modernized, the quality of the products offered and the efficiency of production and sales have improved.

Assuming that the industrial model is more efficient, but not conducive to the long-term development of agriculture, and that the paradigm of sustainable development prefers smaller farms as the

${ }^{3}$ Agency for Restructuring and Modernization of Agriculture and Rural Development website armir.gov.pl [Accessed 20.01.2018]. 
Proceedings of the 2018 International Scientific Conference 'Economic Sciences for Agribusiness and Rural Economy' No 1, Warsaw, 7-8 June 2018, pp. 21-27

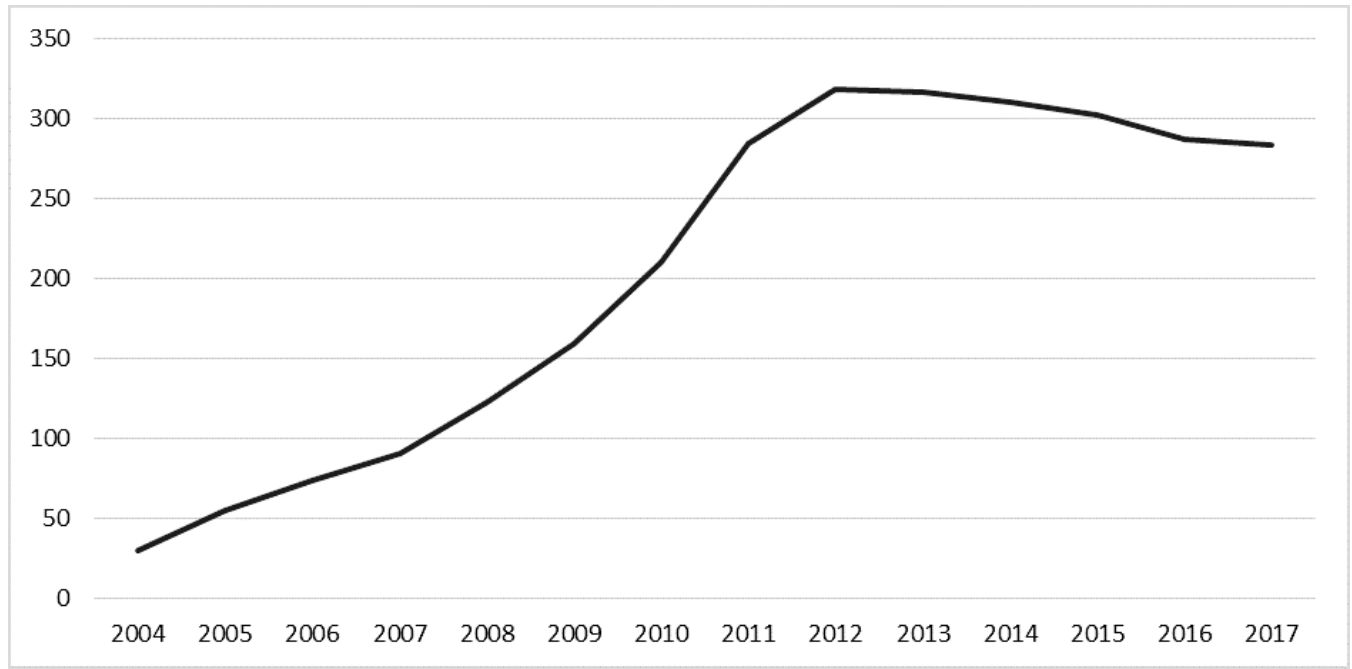

Figure 1. Number of producer groups and organizations from 2004 to 2017

Source: own study based on data from the Agency for Restructuring and Modernization of Agriculture and Rural Development (ARMA) and the Ministry of Agriculture and Rural Development (MRDA).

more efficient ones, the concept of creating producer groups and organisations combines the advantages of both agrarian theories. As smaller producer groups, producer groups set up within the framework of institutional interventionism make it possible to take advantage of the advantages of the industrial trend while maintaining the often family type of agriculture which cares for the well-being of the environment. In Poland, producer groups and organizations are conducive to the implementation of the sustainable development paradigm, as we are mostly dealing with small, often family organizations (Fig. 2).

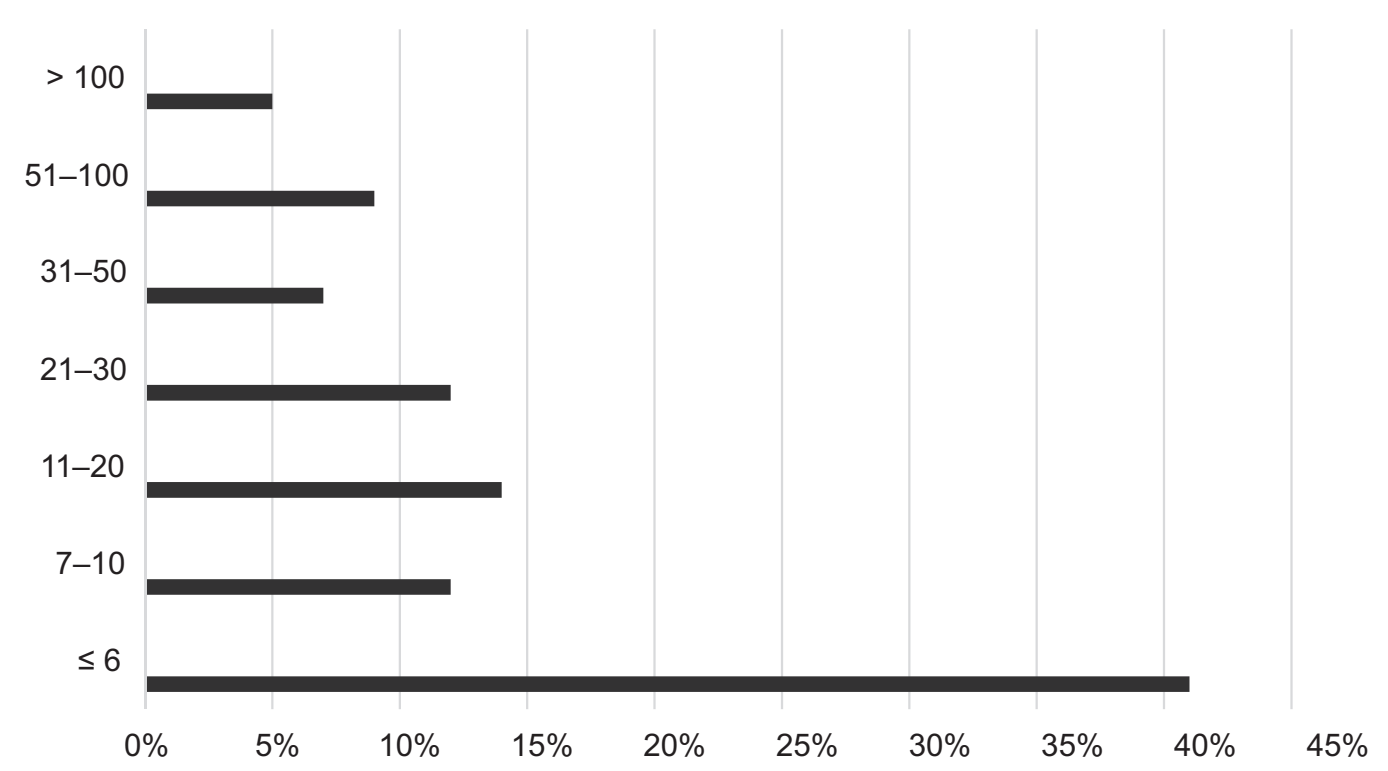

Figure 2. Structure of fruit and vegetable producer groups and organizations by number of members (situation on 2 January 2018)

Source: see Figure 1. 
However, it should be remembered that only the process of ownership changes without adequate institutional solutions will not automatically ensure sustainable economic development (Czyżewski ed., 2007). As mentioned earlier, the functioning of fruit and vegetable producer groups and organizations in Poland was initiated by institutional procedures. Their appearance undoubtedly had an impact on the fruit and vegetable market. The average annual rate of changes in selected factors characterizing this market in the years 2004-2016 is presented in Table 1.

On the basis of this information, we can see that fruit and vegetable producers reduced their area of land dedicated mainly to vegetables on average each year during the period under analysis (the area devoted to fruit production decreased very slightly).
Despite the changes in the cultivated area, the yield increased on average by $2.3 \%$ per year for fruit and slightly for vegetables. Taking into account the fact that the consumption of both fruit and vegetables decreased on average by $0.5 \%$ annually, it is not surprising that the importance of an open market and the possibility of exporting fruit and vegetables have increased. The increase in export value emphasized the advantages of Polish horticulture products, as its annual average value increased by approx. $8 \%$. The following indicates whether there is a correlation between the selected characteristics and the number of fruit and vegetable producer groups and organizations. The data for the period 2004-2016 have been calculated using Statistica with a materiality level of $\mathrm{p}<0.05$ and are presented in Table 2.

Table 1. Average annual rate of changes in selected factors on the fruit and vegetable market in the years 2004 $-2016$

\begin{tabular}{|c|c|c|c|c|c|c|c|}
\hline 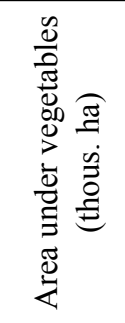 & 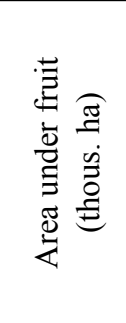 & 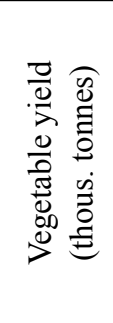 & 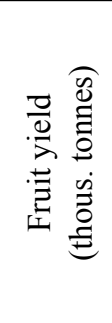 & 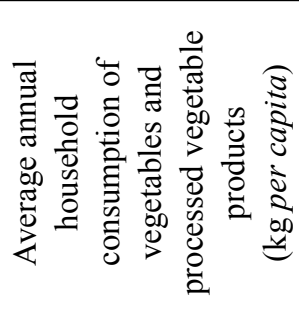 & 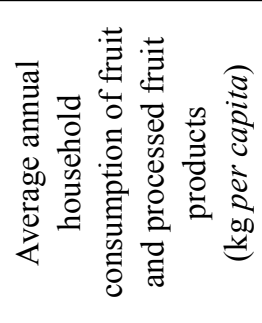 & 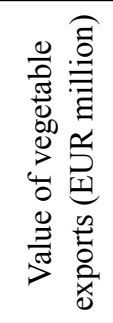 & 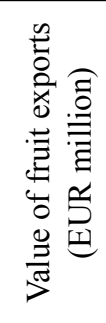 \\
\hline-0.0142 & -0.0005 & 0.0003 & 0.0233 & -0.0057 & -0.0053 & 0.0821 & 0.0786 \\
\hline
\end{tabular}

Source: own study based on data from the Central Statistical Office (GUS).

Table 2. Correlations between selected characteristics of the fruit and vegetable market and the number of producer groups and organizations 2004-2016

\begin{tabular}{|c|c|c|c|c|c|c|c|c|c|c|}
\hline 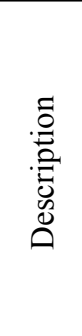 & 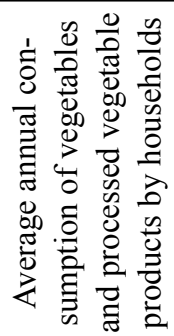 & 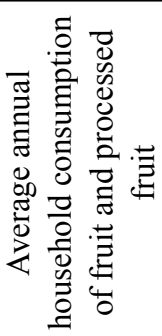 & 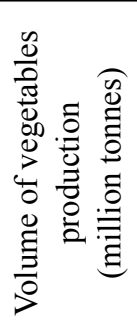 & 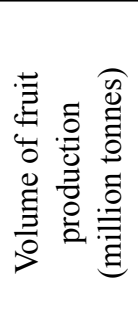 & 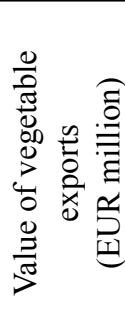 & 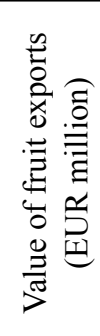 & 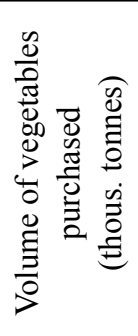 & 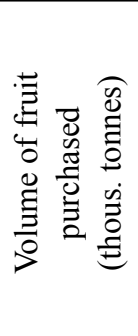 & 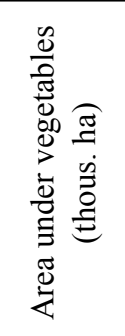 & 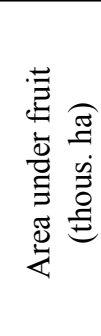 \\
\hline 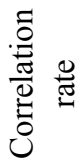 & -0.8099 & -0.4967 & -0.0629 & 0.6078 & 0.9155 & 0.9218 & 0.9382 & 0,8867 & -0.8669 & 0.4421 \\
\hline
\end{tabular}

Source: own study based on data from the Central Statistical Office (GUS) and the Agricultural Market Agency (ARMA). 
Relations between the growing number of fruit and vegetable producer groups have been noted, despite decreasing internal demand. This phenomenon is explained by the very strong positive correlation between the growing fruit production and its purchase and export. The intensive production of fruit by individual producers is demonstrated by the lack of a significant correlation between integrated producers and the size of the fruit-growing area. Different relationships were noted for vegetables. Newcomer groups and producer organizations were not correlated with a decrease in internal demand or with a decrease in the volume of vegetable production. The intensification of vegetable production is evidenced by a strong correlation between the number of groups/organizations and the decreasing area of land allocated for vegetable production. Moreover, it should be noted that there was a dependence indicating the role of groups and organizations in increasing the volume of vegetables purchased and the value of their exports. This confirms the effectiveness of modernization processes in Polish integrated horticultural farms, mainly in the vegetable sector.

\section{CONCLUSIONS}

To sum up, we can state that institutional regulations of the fruit and vegetable market since the accession of Poland to the EU caused the initiation of concentration processes indicating the predominance of the idea of industrial agriculture. However, the number of Polish fruit and vegetable producer groups and organizations is conducive to the implementation of the concept of sustainable agriculture. The characteristics of the fruit and vegetable market over the period under analysis confirm an increase in the number of products marketed, which is an indication of the characteristics of industrial agriculture. The dual model, which combines the advantages of industrial production with those of resource-conscious farms in terms of environmental or health requirements, can be a concept that should be promoted institutionally. However, experience with the scheme so far has shown that support for the fruit and vegetable market should be of a long-term character. Research shows that the possibility of benefiting from a high 'political rent' has encouraged many horticulturists to integrate, which was later corrected by the market. Without further intervention one can fear that as soon as the groups/organizations started to appear on the Polish market, they may disappear from it just as quickly. It would be a pity if modernized farms/enterprises were taken over by partners geared strictly towards the industrial economy.

\section{REFERENCES}

1. Czyżewski, A. (2007). Makroekonomiczne uwarunkowania rozwoju sektora rolnego [Macroeconomic conditions for the development of the agricultural sector]. In: Czyżewski, A. (ed.) Uniwersalia polityki rolnej w gospodarce rynkowej. Ujęcie makroi mikroekonomiczne [Universality of agricultural policy in market economy. Macro- and microeconomic approaches]. Wydawnictwo Akademii Ekonomicznej w Poznaniu, Poznań,pp. 15-56.

2. Czyżewski, A., Czyżewski, B. (2015). Ziemia i jej renty w nowym paradygmacie rozwoju rolnictwa [Land and its rents in the new paradigm of agricultural development]. In: Czyżewski, A. and Klepacki, B. (eds.) Problemy rozwoju rolnictwa i gospodarki żywnościowej w pierwszej dekadzie członkostwa Polski i Unii Europejskiej [Problems of development of agriculture and food economy in the first decade of membership of Poland and the European Union]. PTE, Warszawa, pp. 27-41.

3. Czyżewski, A., Guth, M. (2016). Zróżnicowanie produkcji mleka w makroregionach Unii Europejskiej z wyróżnieniem Polski [Diversification of milk production in the macro-regions of the European Union with distinction of Poland]. Wydawnictwo Naukowe PWN, Warszawa.

4. Czyżewski, A., Smędzik-Ambroży, K. (2013). Intensywne rolnictwo $\mathrm{w}$ procesach specjalizacji i dywersyfikacji produkcji rolnej. Ujęcie regionalne i lokalne [Intensive agriculture in processes of specialisation and diversification of agricultural production. Regional and local approaches]. Wydawnictwo Naukowe PWN, Warszawa.

5. Grzelak, A. (2007). Endogeniczne uwarunkowania powiązań gospodarstw rolnych z otoczeniem rynkowym [Endogenous conditions of connections of agricultural holdings with the market environment]. In: Czyżewski, A. (ed.) Uniwersalia polityki rolnej w gospodarce rynkowej. Ujęcie makro- i mikroekonomiczne [Universality of agricultural policy in market economy. Macro- and 
microeconomic approaches]. Wydawnictwo Akademii Ekonomicznej, Poznań, pp. 185-208.

6. Henisz-Matuszczak, A. (2007). Dualny rozwój rolnictwa i obszarów wiejskich [Dual development of agriculture and rural areas]. In: Czyżewski, A. (ed.) Uniwersalia polityki rolnej w gospodarce rynkowej. Ujęcie makro- i mikroekonomiczne [Universality of agricultural policy in market economy. Macro- and microeconomic approaches]. Wydawnictwo Akademii Ekonomicznej w Poznaniu, Poznań, pp. 99-120.

7. Kopiński, Ł., Czernyszewicz, E. (2014). Grupy o organizacje producentów w ogrodnictwie w Polsce w latach 2004-2014 [Groups of producer organisations in horticulture in Poland in the years 2004-2014]. Annales Universitatis Mariae Curie-Skłodowska, Sectio EEE 24 (4), pp. 51-60.

8. Krzyżanowska, K. (2011). Stan zorganizowania rolników w grupy producentów owoców i warzyw w Polsce [The state of organisation of farmers into fruit and vegetable producer groups in Poland]. Roczniki Naukowe SERiA, 13 (2), pp. 256-260.

9. Matysiak, A., Struś, M. (2015). Paradygmat rozwoju zrównoważonego [A paradigm of sustainable development]. Studia Ekonomiczne. Zeszyty Naukowe Uniwersytetu Ekonomicznego w Katowicach, 213, pp. 11-21.

10. Smędzik-Ambroży, K. (2015). Konwergencja czy dywergencja rolnictwa w Polsce w latach 2004-2011 [Convergence or divergence of agriculture in Poland in the period 2004-2011]. In: Czyżewski, A. and Klepacki, B. (eds.) Problemy rozwoju rolnictwa i gospodarki żywnościowej w pierwszej dekadzie członkostwa Polski i Unii Europejskiej [Problems of development of agriculture and food economy in the first decade of membership of Poland and the European Union]. PTE, Warszawa, pp. 110-129.

11. Sobczak, W., Jabłońska, L., Olewnicki, D. (2013). Stopień zorganizowania producentów owoców i warzyw $\mathrm{w}$ Polsce [Degree of organisation of fruit and vegetable producers in Poland]. Zeszyty Naukowe SGGW w Warszawie. Problemy Rolnictwa Światowego, 13 (28), 1, pp. 119-127.

12. Sobczyński, T. (2015). O konieczności intensyfikacji produkcji rolniczej i wdrażania zasad zrównoważonego rozwoju [The need to intensify agricultural production and implement the principles of sustainable development]. In: Czyżewski, A. and Klepacki, B. (eds.) Problemy rozwoju rolnictwa i gospodarki żywnościowej w pierwszej dekadzie członkostwa Polski i Unii Europejskiej [Problems of development of agriculture and food economy in the first decade of membership of Poland and the European Union]. PTE, Warszawa, pp. 130-153.

13. Zegar, J.S. (2010). Przesłanki nowej ekonomii agrarnej we współczesnym świecie [The rationale of the new agrarian economy in the modern world]. Zeszyty Naukowe Uniwersytetu Ekonomicznego w Poznaniu, 150, pp. 11-28. 